B. JIANG ${ }^{1}$, G. YAO ${ }^{1}$, C. YAO ${ }^{1}$, Yu. ZHANG',

J. GE', and E. QIU'

\title{
VASCULAR COGNITIVE IMPAIRMENT WITH NO DEMENTIA: NEUROPSYCHOLOGY, BRAIN IMAGING, AND EVENT-RELATED POTENTIALS
}

\author{
Received November, 22, 2012.
}

We investigated the neuropsychological characteristics, cranial MRI, and P300 ERPs in patients suffering from vascular cognitive impairment with no dementia (VCIND). A study was performed on 68 cases of VCIND after stroke. The cranial MRI patterns and P300 waves of the patients were compared with those of 56 stroke patients without cognitive impairment and 52 healthy subjects. The MoCA (Montreal Cognitive Assessment) was also used to assess their mental status. The proportion of patients with frontotemporal lesions, multiple lesions, and leukoaraiosis (LA) in the VCIND group was greater than that in the stroke group. The cognitive impairment in patients with the former deficiencies was more significant. The MoCA scores in the VCIND group were significantly lower, and the P300 latency was significantly longer, as compared with other two groups. The P300 latency inversely correlated with the MoCA score. Patients with frontotemporal lesions, multiple lesions, and LA are susceptible to cognitive impairment. The MoCA score and the P300 test are helpful for the early diagnosis of VCIND.

Keywords: cognitive impairment, cerebrovascular disorders, MRI, neuropsychology, event-related potentials, P300.

\section{INTRODUCTION}

Vascular cognitive impairment (VCI) describes a broad class of syndromes, from mild cognitive disorders to dementia caused by cerebrovascular risk factors and obvious or not obvious cerebrovascular diseases. The latter cover the whole process of VCI, from a mild to a severe degree, and include vascular cognitive impairment with no dementia (VCIND), vascular dementia, mixed dementia, and other types [1]. VCIND refers to the early or mild cognitive impairment caused by cerebrovascular damage [2]. VCIND is a hidden disease, and the degree of cognitive impairment usually does not reach the diagnostic criteria for clear dementia [1]. The incidence rate of VCIND is reportedly about $26.9 \%$ at 3 months after a

\footnotetext{
${ }^{1}$ Department of Neurology, the First Hospital Affiliated to the Chinese PLA General Hospital, Beijing, China.

Correspondence should be addressed to Bo Jiang

(e-mail: bojiangcn@126.com).
}

stroke [3]. Early diagnosis and adequate intervention for VCIND patients can improve the prognosis; otherwise, VCIND will progress into dementia [4]. Studies on VCI have mainly been focused on vascular dementia; thus, research on VCIND, which has the best clinical intervention result, remains relatively limited. The pathogenic factors of VCIND have not been fully determined, and methods for early diagnosis are lacking. Our study aimed to observe the neuropsychological, imaging, and P300 characteristics of VCIND patients to improve the early diagnostic rate and provide a basis for early intervention.

\section{METHODS}

Subjects. A total of 68 VCIND cases (42 men and 26 women, inpatients and outpatients) who had a stroke were included in the study. The patients, 44- to 78-year-old, with a mean age of $64 \pm 2.4$ years, were recruited between 2006 and 2011. The diagnostic criteria for VCIND (based on the criteria by Rockwood et al. [2]) are as follows: presence of a cerebrovascular 
disease, neuropsychological evaluation (including evidence of cognitive impairment), cognitive impairment occurring within 3 months after stroke, a causal relationship between cerebrovascular disease and cognitive impairment, excluding other diseases, and Hanchinski ischemic score $\geq 7$ not meeting the dementia diagnosis criteria. The exclusion criteria included Alzheimer's disease and the presence of other conditions, such as mental retardation, depression, mental disease, and aphasia that affects the Montreal Cognitive Assessment (MoCA) score.

Fifty-six (30 men and 26 women) patients with stroke (outpatients and inpatients) were also included as subjects. These subjects were 38- to 76-year-old, with an average age of $63 \pm 2.5$ years. Stroke was diagnosed in accordance with the diagnostic criteria [5] amended by the European Stroke Initiative and confirmed by cranial MRI, with the scale assessment. A clinical and cognitive function test was performed for patients without cognitive impairment.

Fifty-two control cases (32 men and 20 women), healthy individuals that checked into the hospital at the same time, were also included. The members of this group were from 35 to 72 year old, with an average age of $63 \pm 3.57$ years. They had no obvious lesions and no cognitive impairment under the clinical and cognitive function test.

Cranial MRI. The MRI imaging studies were carried out on a Novus $1.5 \mathrm{~T}$ superconducting MRI (Siemens, Germany). The patients were subjected to an axial T1WI, T2WI, FLAIR, and DWI, and the location of the stroke lesions, their number, and the presence of leukoaraiosis (LA) were observed. Leukoaraiosis is defined as sites of periventricular or deep white matter with a high signal intensity and no clear edges under T2WI and FLAIR; DWI does not show obviously high signals, and TIWI shows equal or slightly lower signals. Leukoaraiosis excludes the decreased white matter density caused by multiple sclerosis, intracranial infection, radiation encephalopathy, anthracemia, hypotension, anemia, demyelinating disease, adrenoleukodystrophy, and other diseases.

Cognitive Function Check. The MoCA assessment scale was used to evaluate the cognitive function of the patients. The MoCA has 11 items assessing eight cognitive domains. These domains include visuospatial/executive abilities, naming, memory, attention, language, abstraction, delayed recall, and calculation ability, with a total possible score of 30 . One more score is added for subjects with less than 12 years of education. The higher the score, the better is the cognitive function of the subject; MoCA scores below 26 indicate cognitive impairment.

P300 Wave. Recording of this ERP was performed in all patients within $48 \mathrm{~h}$ after they were enrolled in the study. A Britain Oxford's multimedia EMG/EP system was adopted. In a quiet shielded room, the subjects were asked to lie supine, remain calm, and concentrate. According to the international 10/20 EEG system, a recording electrode was placed along the central line, a reference electrode was placed on the right earlobe, and a ground electrode was on the forehead. The electrode impedance was maintained below $5 \mathrm{k} \Omega$, and the analysis time was $600 \mathrm{msec}$. Short sound stimulation was used in the experiment. The probability for nontarget stimulation (frequency $1,000 \mathrm{~Hz}$ ) showed regularly was $80 \%$ at a signal strength of $80 \mathrm{~dB}$. The probability for target stimulation (frequency $4,000 \mathrm{~Hz}$ ) showed randomly and alternated with nontarget stimulation was $20 \%$ at a signal strength of $90 \mathrm{~dB}$. The subjects were instructed to press a key for target stimulation, and the instrument automatically recorded the response time. The test was repeated twice, and the means were calculated.

Statistical Analysis. SPSS 16.0 statistical software was used to analyze the data. The measured data were expressed as means \pm s.e.m. The ANOVA and $t$-test were performed. The counting data were indicated by percentage, and the $\chi^{2}$ test was performed. Pearson's correlation analysis was also used to analyze the data. Differences with $P<0.05$ were considered statistically significant.

\section{RESULTS}

Comparison of General Characteristics. The three examined groups did not differ from each other in terms of gender composition and cultural degree. The proportion of patients with diabetes mellitus and smoking history in the VCIND group was higher than those in other two groups. The proportion of patients with hypertension and hyperlipidemia in the VCIND group was higher than that in the control group (Table 1).

Cognitive Function. The total MoCA scores of the VCIND patients were significantly lower than those of other two groups $(P<0.01)$. The total MoCA scores of the stroke group did not significantly differ from those of the control group. The MoCA subitems in the VCIND group were lower than those in the stroke group, whereas the MoCA scores of the control group 
TABLE 1. Comparison of Basic Clinical Data among Three Groups

Т а б л и ц я 1. Порівняння основних клінічних даних у паціснтів трьох груп

\begin{tabular}{|c|c|c|c|c|c|c|c|c|c|c|c|c|c|c|}
\hline \multirow[b]{2}{*}{ Group } & \multirow[b]{2}{*}{$\begin{array}{l}\text { Number } \\
\text { of cases }\end{array}$} & \multicolumn{2}{|c|}{ Gender } & \multicolumn{3}{|c|}{ Educational level } & \multicolumn{2}{|c|}{ Focal areas } & \multicolumn{2}{|c|}{ Lesion number } & \multirow[b]{2}{*}{$\begin{array}{l}\text { Hyper- } \\
\text { tension }\end{array}$} & \multirow[b]{2}{*}{$\begin{array}{c}\text { Diabe- } \\
\text { tes }\end{array}$} & \multirow[b]{2}{*}{$\begin{array}{c}\text { Hyper- } \\
\text { lipid- } \\
\text { emia }\end{array}$} & \multirow[b]{2}{*}{$\begin{array}{l}\text { Smok- } \\
\text { ing } \\
\text { history }\end{array}$} \\
\hline & & men & women & $\begin{array}{c}\text { uni- } \\
\text { versity }\end{array}$ & $\begin{array}{c}\text { senior } \\
\text { high } \\
\text { school }\end{array}$ & $\begin{array}{c}\text { junior } \\
\text { high } \\
\text { school }\end{array}$ & $\begin{array}{l}\text { fronto- } \\
\text { temporal } \\
\text { lobar }\end{array}$ & other & multiple & single & & & & \\
\hline VCIND & 68 & $42(61.76)$ & $26(38.24)$ & $9(13.24)$ & $51(75.00)$ & $8(11.76)$ & $30(44.12)$ & $38(55.88)$ & $43(63.24)$ & $25(36.76)$ & $33(48.53)$ & $38(55.88)$ & $30(44.12)$ & $37(54.41)$ \\
\hline Stroke & 56 & $30(53.57)$ & $26(46.43)$ & $6(10.71)$ & $45(80.36)$ & $5(8.93)$ & $11(19.64)$ & $45(80.36)$ & $22(39.29)$ & $34(60.71)$ & $24(42.86)$ & $16(28.57)$ & $22(39.29)$ & $13(23.21)$ \\
\hline Control & 52 & $32(61.54)$ & $20(38.46)$ & $7(13.46)$ & $40(76.92)$ & $5(9.62)$ & & & & & $13(25.00)$ & $12(23.08)$ & $9(17.31)$ & $12(23.08)$ \\
\hline \multicolumn{15}{|c|}{$\begin{array}{l}\text { Comparison } \\
\text { among groups }\end{array}$} \\
\hline$\left(\chi^{2}\right)$ & & \multicolumn{2}{|c|}{1.76} & \multicolumn{3}{|c|}{0.96} & \multicolumn{2}{|c|}{$8.31^{* * *}$} & \multicolumn{2}{|c|}{$7.06^{* * *}$} & $10.56^{* *}$ & $15.84^{* *}$ & $8.80^{*}$ & $19.36^{* *}$ \\
\hline
\end{tabular}

Footnotes. Case and percentage (in brackets) are shown. ${ }^{* *} \mathrm{P}<0.01$ and ${ }^{*} \mathrm{P}<0.05$.

TABLE 2. Comparison of the MoCA Rating Scale among Three Groups (Score)

Т а б л и ц я 2. Порівняння оцінок за рейтинговою шкалою МоСа у паціснтів трьох груп

\begin{tabular}{l|c|cc}
\hline \multicolumn{1}{c|}{ Item } & $\begin{array}{c}\text { VCIND } \\
(68 \text { cases })\end{array}$ & $\begin{array}{c}\text { Stroke } \\
(56 \text { cases })\end{array}$ & $\begin{array}{c}\text { Control } \\
(52 \text { cases })\end{array}$ \\
\hline Memory ability & $3.71 \pm 0.77^{* *}$ & $4.67 \pm 0.68$ & $4.70 \pm 0.47$ \\
Language fluency & $2.71 \pm 0.47$ & $2.71 \pm 0.46$ & $2.75 \pm 0.44$ \\
Vision space/executive ability & $2.59 \pm 0.87^{* *}$ & $4.67 \pm 0.48$ & $4.70 \pm 0.46$ \\
Naming ability & $2.71 \pm 0.47$ & $2.95 \pm 0.22$ & $2.75 \pm 0.44$ \\
Attention and computing ability & $4.06 \pm 0.90^{* *}$ & $5.48 \pm 0.51$ & $5.55 \pm 0.60$ \\
Abstract epitome ability & $1.40 \pm 0.51^{*}$ & $1.71 \pm 0.46$ & $1.80 \pm 0.41$ \\
Orientation ability & $5.24 \pm 0.56$ & $5.57 \pm 0.51$ & $5.45 \pm 0.60$ \\
Total & $22.18 \pm 1.62^{* *}$ & $27.76 \pm 1.14$ & $27.70 \pm 1.08$
\end{tabular}

Footnotes. Means \pm s.e.m. are shown. One and two asterisks show cases of significant difference $v s$ two other groups with $P<0.05$ and $P<0.01$, respectively.

differed significantly $(P<0.05$, Table 2$)$ in terms of memory, visuospatial/executive abilities, attention, and abstract ability. However, the MoCA subitem scores in the stroke group did not differ significantly from those in the control group.

Number of Lesions, Lesion Position, LA, and Cognitive Function of VCIND Patients. The proportion of patients with frontotemporal lesions in the VCIND group was $55.9 \%$, i.e., much higher than that in the stroke group $\left(19.6 \%, \chi^{2}=8.31, P<0.01\right)$. The proportion of the patients with frequently occurring lesions was $63.2 \%$, also higher than that in the stroke group $\left(39.3 \%, \chi^{2}=7.06, P<0.01\right)$. The proportion of patients with LA in the VCIND group was $58.8 \%$, also significantly higher than that in the stroke group $\left(30.4 \%, \chi^{2}=10.02, P<0.01\right)$. The proportion of the lesions in the left cerebral hemisphere in the VCIND group was $67.6 \%$, which did not significantly differ from that in the stroke group $\left(57.1 \%, \chi^{2}=1.45, P>0.05\right)$. The position of lesions, the number of lesions, and the presence of LA in the VCIND group directly affected the degree of impairment of the cognitive function. More lesions corresponded to lower MoCA scores and greater degrees of impairment of the cognitive function for patients with frontotemporal lesions and patients with LA (Table 3).

P300 Characteristics. The P300 latencies for patients of the VCIND group were significantly longer than those in the stroke and control groups 
TABLE 3. Numbers of Lesions, Position of Lesions, Leukoaraiosis, and Cognitive Function in VCIND Patients

Т а б л и ц я 3. Кількість уражень мозку, їх локалізація, кількість випадків лейкоарайозу та оцінка когнітивних функцій у паціснтів з VCIND

\begin{tabular}{|c|c|c|c|c|c|c|}
\hline Group & \multicolumn{2}{|c|}{ Number of lesions } & \multicolumn{2}{|c|}{ Position of lesions } & \multicolumn{2}{|c|}{ Leukoaraiosis } \\
\hline $\begin{array}{l}\text { Number of } \\
\text { cases }\end{array}$ & 43 & 25 & 30 & 38 & 40 & 28 \\
\hline $\mathrm{MoCA}$ & $22.00 \pm \_1.83$ & $23.70 \pm 1.83$ & $21.90 \pm \ldots 1.37$ & $23.60 \pm 0.84$ & $21.80 \pm \_1.03$ & $23.30 \pm 0.67$ \\
\hline $\mathrm{T}$ value & \multicolumn{2}{|c|}{2.55} & \multicolumn{2}{|l|}{3.34} & \multicolumn{2}{|c|}{3.85} \\
\hline
\end{tabular}

Footnote. Means \pm s.e.m. are shown.

TABLE 4. Comparison of Latency and Amplitude of the Central-Line P300 between the Groups

Т а б л и ц я 4. Міжгрупове порівняння латентних періодів та амплітуд потенціалу Р300 (відведення по центральній лінії) у пацієнтів і контрольних суб'єктів

\begin{tabular}{l|c|c|c}
\hline Group & $\begin{array}{c}\text { Number of } \\
\text { cases }\end{array}$ & P300 latency, msec & P300 amplitude, $\mu$ V \\
\hline VCIND & 68 & $379.12 \pm 25.68^{* *}$ & $4.04 \pm 0.75$ \\
Stroke & 56 & $325.10 \pm 13.52$ & $4.25 \pm 0.74$ \\
Control & 52 & $324.27 \pm 11.74$ & $3.96 \pm 0.49$ \\
F value & & 144.66 & 2.02 \\
$P$ value & & 0.000 & 0.136 \\
\hline
\end{tabular}

Footnotes. Means \pm s.e.m. are shown. Two asterisks show significant difference in comparison of the VCIND group $v s$ the other two groups with $P<0.01$.

$(P<0.01)$. No significant difference in the P300 latency was observed between the stroke group and the control group $(P>0.05)$. The P300 amplitude did not show significant differences among the three groups $(P>0.05$, Table 4$)$.

Correlation between the P300 Parameters and MoCA. Correlation analysis was carried out among the P300 latency, amplitude, and MoCA score of the VCIND group. The MoCA score inversely correlated with the P300 latency $(\rho=-0.798, P=0.001)$, but did not correlate significantly with the amplitude of this wave $(\rho=0.057, P=0.846)$.

\section{DISCUSSION}

Searching for the related pathogenic factors, simple and effective test methods, and methods for early detection of mild cognitive function impairment is necessary for adequate treating of VCIND patients.

Many studies demonstrated that vascular cognitive impairment is related to the risk factors of cerebrovascular diseases, the characteristics of stroke, and the characteristics of the patient. At present, diabetes, hypertension, heart diseases, and other disorders are believed to be related to the occurrence of cognitive impairment. However, compared to other factors, diabetes is more closely related to vascular cognitive impairment [6] because it causes cerebral arteriosclerosis, microcirculation disturbance, and small-vessel disease. Finally, it leads to neuronal degeneration, which causes cognitive function impairment. In our study, the incidence of diabetes mellitus was clearly higher in the VCIND group 
than in other groups, which indicates that diabetes may be more closely related to cognitive function impairment. Smoking is an independent risk factor for cerebrovascular diseases. The proportion of patients who smoke in the VCIND group was evidently higher than that in the stroke group, which is in accordance with the related reports that smoking increases the risk of stroke. Smoking also positively correlated with cognitive function impairment [7].

A few studies reported that the number and position of cerebral infarcts correlate with the degree of cognitive impairment. Straaten et al. [8] found that a history of stroke recurrence and multiple strokes are important causes for sharp declines in cognitive function. Our findings indicate that the VCIND group had more lesions compared with the stroke group. Within the VCIND group, the patients with multiple lesions had lower MoCA scores than patients with single lesions. Considering that the number of lesions is related to the level of cognitive function, it might also be related to the cumulative brain damage caused by multiple lesions and the influence of disorders in the frontal subcortical loop. Some researchers reported that lesions in the left cerebral hemisphere, forebrain, and frontal lobe might play more important roles in the occurrence of cognitive impairment [9]. We found that the proportion of frontotemporal lesions in the VCIND group was higher than that in the stroke group. Meanwhile, the patients in the VCIND group with frontotemporal lesions had lower MoCA scores than patients with lesions at other locations. This agrees with the statement that the frontotemporal lobe is more closely related to cognitive functions. The proportion of left cerebral hemisphere lesions did not differ significantly between the two groups. This observation contrasts with the results of the mentioned report; however, the discrepancy may be related to the fewer number of cases.

Leukoaraiosis is a term used in imaging diagnosis coined by Hachinski in 1987 [10] to describe a group of diseases caused by multiple pathogenic factors that lead to nonspecific changes in the cerebral white matter. At present, LA is considered a part of the human aging process that can lead to cognitive impairment [11]. The specific mechanism and the pathogenic changes in the periventricular white matter affect three limbic loops, the Papez circuit, the Livingston circuit, and the defensive circuit, which are related to memory, emotion, behavior, and other intellectual abilities [12]. The incidence of LA in the VCIND group was obviously higher than that in the stroke group. In addition, the patients with LA in the VCIND group clearly showed signs of decline in the cognitive function, which indicates that LA patients are susceptible to impaired cognitive function.

Cognitive function tests play an important role in diagnosing VCI at an early stage. Nasreddine et al. [13] formulated the MoCA scale basing on their clinical experience, with reference to the cognitive project settings and scoring criteria of the mini-mental state examination. Lee et al. [14] indicated that the MoCA scale provides comparatively high sensitivity and specificity for mild cognitive function impairment. We found that, compared with the stroke control groups, the VCIND patients clearly had greater cognitive function impairment, and their total MoCA score was lower than that in other two groups. The subitems mainly show impairment in memory, visuospatial/ executive functions, attention, calculation, and abstract ability. The above-mentioned study indicated that MoCA is applicable for VCI screening, which coincides with our current results.

The P300 ERP is a forward electrotropic change developing within about $300 \mathrm{msec}$ after target stimulation. All kinds of sensory modes can induce the endogenous P300 component. The effects of physical stimulation parameters on this wave are minimal, but the P300 characteristics are closely related to advanced psychological activities and cognitive processing in the human brain. The P300 reflects multilevel psychological activities, such as memory, perception, understanding, judgment, and emotions; recording of this potential is widely applied in cognitive function research [15]. The P300 latency reveals the evaluation of the stimulation during cognitive activities, and it indicates the information processing rate. Its amplitude indicates the degree of mobilization of effective resources when the brain processes information, and it also indicates the excitability of the brain [16]. Our results and findings of other authors indicate that the P300 latency reflects, to some extent, other aspects of the functional status of the brain, including such characteristics as sensation, attention, memory, information coding, cognitive integration rate, and other activities [17]. The amplitudes of the two P300 components did not differ significantly from each other in our study, which was probably related to the mildness of the cognitive function impairment in the VCIND patients and also to large individual differences. Meanwhile, the P300 latency in the VCIND group was significantly longer compared with that in the control group, which may 
be indicative of the rather high sensitivity of the P300 latency. The latter parameter of P300 in the VCIND group showed abnormalities when cognitive function was mildly impaired. Braverman et al. [18] found that a longer P300 latency could be used to predict early cognitive decline, which coincides with our current results. Bennys et al. [19] reported that the P300 latency is longer among patients with mild cognitive impairment, and it inversely correlates with the MMSE score. Correlation analysis in our study showed that the P300 latency negatively correlates with the MoCA score. This result confirms that prolonged P300 latencies objectively reflect mild cognitive function impairment, and this phenomenon cannot be used to determine the cognitive function impairment related to the impaired neurological function after stroke.

In conclusion, stroke patients with frontotemporal lesions and multiple lesions and also patients with LA are susceptible to cognitive impairment. VCIND patients have obvious abnormalities in neurological characteristics and P300 latencies. The cognitive function impairment in these patients can be detected earlier by combining neurological tests with the P300 test, which will facilitate timely intervention and improve prognosis.

Considering that the studied subjects were mostly elderly persons, even small numbers of cases qualify for the study. The results of the study are also dependent on the sensitivity of the cognitive function determination scale. The relatively small number of subjects limits the applicability of the results to VCIND patients, which should be improved by increasing the sampling size and other methods in future studies.

This study was carried out in accordance with the Declaration of Helsinki and with approval from the Ethics Committee of The First Hospital Affiliated to the Chinese PLA General Hospital. Written informed consent was obtained from all participants.

The authors, B. Jiang, G. Yao, C. Yao, Yu. Zhang, J. Ge, and E. Qiu, confirm that they have no conflict of interests.

Бо Джіан ${ }^{1}$, Гуоєн Яо ${ }^{1}$, Куншан Яо ${ }^{1}$ Юнян Жан ${ }^{1}$, Джунлін Ге

РОЗЛАДИ КОГНІТИВНИХ ФУНКЦІЙ ПРИ СУДИННИХ ЗАХВОРЮВАННЯХ $З$ ВІДСУТНІСТЮ ДЕМЕНЦІЇ: НЕЙРОПСИХОЛОГІЧНІ ХАРАКТЕРИСТИКИ, ДАНІ МАГНІТОРЕЗОНАНСНОГО ДОСЛІДЖЕННЯ ТА ПОВ'ЯЗАНІ 3 ПОДІЄЮ ЕЕГ-ПОТЕНЦІАЛИ

${ }^{1}$ Перший шпиталь при Центральній лікарні PLA, Пекін (Китай).
Р е $з$ ю м е

Ми досліджували нейропсихологічні характеристики, дані магніторезонансного дослідження мозку (MRI) та пов'язані 3 подією ЕЕГ-потенціали Р300 у пацієнтів зі зумовленим судинними захворюваннями ураженням когнітивних функцій при відсутності деменції (VCIND). Дослідження було проведено у 68 випадках VCIND, котре розвивалося після інсульту. Дані MRI та характеристики P300 у групі VCIND порівнювали з такими у двох інших групах (у 56 пацієнтів після інсульту без розладів когнітивних функцій та у 52 здорових суб'єктів). Шкалу МоСА (Монреальська когнітивна оцінка) використовували для оцінки інтелектуального статусу обстежених. Відносна кількість випадків фронтотемпоральних уражень, множинних уражень та лейкоарайозу (ЛА) у групі VCIND була більшою, ніж у групі пацієнтів 3 неускладненим інсультом. Розлади когнітивних функцій у пацієнтів із зазначеними вище ураженнями були більш істотними. Оцінки згідно з MoCA в групі VCIND були достовірно нижчими, а латентний період Р300 був істотно тривалішим, ніж у двох інших групах. Пацієнти 3 фронтотемпоральними та множинними ураженнями й ЛА особливо схильні до когнітивних розладів. Використання оцінок за МоСА та відведення потенціалу Р300 є вельми доцільними в аспекті ранньої діагностики VCIND.

\section{REFERENCES}

1. J. L. Ingles, C. Wentzel, J. D. Fisk, and K. Rockwood, "Neuropsychological predictors of incident dementia in patients with vascular cognitive impairment, without dementia," Stroke, 33, No. 8, 1999-2002 (2002).

2. K. Rockwood, K. Howard, C. MacKnight, and S. Darvesh, "Spectrum of disease in Vascular cognitive impairment," Neuroepidemiology, 18, No. 5, 248-254 (1999).

3. S. Serrano, J. Domingo, E. Rodríguez-Garcia, et al., "Frequency of cognitive impairment without dementia in patients with stroke: a two-year follow-up study," Stroke, $\mathbf{3 8}$, No. 1, 105-110 (2007).

4. B. C. Stephan, F. E. Matthews, K. T. Khaw, et al., "Beyond mild cognitive impairment: vascular cognitive impairment, no dementia (VCIND)," Alzheimer's Res. Ther., 1, No. 1, 1-9 (2009).

5. T. S. Olsen, P. Langhorne, H. C. Diener, et al., "European stroke initiative executive committee; EUSI writing committee. European stroke initiative recommendations for stroke management-update 2003," Cerebrovascul. Dis., 16, PNo. 4, 311-337 (2003).

6. D. W. Desmond, J. T. Moroney, M. C. Paik, et al., "Frequency and clinical determinants of dementia after ischemic stroke," Neurology, 54, No. 5, 1124-1131 (2000).

7. C. Reitz, J. Luchsinger, M. X. Tang, and R. Mayeux, "Effect of smoking and time on cognitive function in the elderly without dementia," Neurology, 65, No. 6, 870-875 (2005).

8. E. C. Van Straaten, P. Scheltens, and F. Barkhof, "MRI and CT in the diagnosis of vascular dementia," J. Neurol. Sci., 226, Nos. 1/2, 9-12 (2004).

9. T. Erkinjuntti, D. Inzitari, L. Pantoni, et al., "Research criteria 
for subcortical vascular dementia in clinical trials," J. Neural Transm., Suppl., 59, 23-30 (2000).

10. V. C. Hachinski, P. Potter, and H. Merskey, "Leukoaraiosis," Arch. Neurol., 44, 21-23 (1987).

11. L. Pantoni, A. Poggesi, and D. Inzitari, "The relation between white-matter lesions and cognition," Current Opin. Neurol., 20, No. 20, 390-397 (2007).

12. R. Barber, A. Gholkar, P. Scheltens, et al., "MRI volumetric correlates of white matter lesions in dementia with lewy bodies and Alzheimer's disease," Int. J. Geriat. Psychiat., 15, No. 10, 911-916 (2000).

13. Z. S. Nasreddine, N. A. Phillips, V. Bédirian, et al., "The montreal cognitive assessment, MoCA: a brief screening tool for mild cognitive impairment," J. Am. Geriat. Soc., 53, No. 4, 695-699 (2005).

14. J. Y. Lee, Dong Woo Lee, S. J. Cho, et al., "Brief screening for mild cognitive impairment in elderly outpatient clinic: validation of the Korean version of the Montreal Cognitive Assessment," J. Geriat. Psychiat. Neurol., 21, No. 2, 104-110 (2008).
15. A. Gironell, C. Garcia-Sanchez, A. Estevez-Gonzalez, et al., "Usefulness of p300 in subjective memory complaints: a prospective study," J. Clin. Neurophysiol., 22, No. 4, 279-284 (2005).

16. W. B. Liu, Q. Z. Chen, H. M. Yin, et al., "Event-related potentials P300 with memory function and psychopathology in first-episode paranoid schizophrenia," Zhejiang Da Xue Xue Bao Yi Xue Ban, 40, No. 6, 647-652 (2011).

17. E. J. Park, S. I. Han, and Y. W. Jeon, "Auditory and visual P300 reflecting cognitive improvement in patients with schizophrenia with quetiapine: a pilot study," Prog. Neuropsychopharmacol. Biol. Psychiat., 34, No. 4, 674-680 (2010).

18. E. R. Braverman, T. J. Chen, J. Schoolfield, et al., "Delayed P300 latency correlates with abnormal test of variables of attention (TOVA) in adults and predicts early cognitive decline in a clinical setting," Adv. Ther., 23, No. 4, 582-600 (2006).

19. K. Bennys, F. Portet, J. Touchon, and G. Rondouin, "Diagnostic value of event-related evoked potentials N200 and P300 subcomponents in early diagnosis of Alzheimer's disease and mild cognitive impairment," J. Clin. Neurophysiol., 24, No. 5, 405-412 (2007). 